\title{
Mite (Arachnida: Acari) diversity and abundance on oil palms in the central region of the Brazilian Amazonia
}

\author{
WILTON PIRES DA CRUZ ${ }^{1}$, CRISTIANE KRUG ${ }^{2}$, GERALDO JOSÉ NASCIMENTO DE \\ VASCONCELOS ${ }^{3} \&$ GILBERTO JOSÉ DE MORAES \\ ${ }^{I}$ Departamento de Fitossanidade, Universidade Estadual Paulista “Júlio de Mesquita Filho”, Via de Acesso Prof. Paulo \\ Donato Castellani, s/n, CEP 14884-900, Vila Industrial, Jaboticabal, SP, Brazil. \\ ${ }^{2}$ Laboratório de Entomologia, Embrapa Amazônia Ocidental, Rodovia AM 010, Km 29, CEP 69011-970, Caixa Postal 319 , \\ Zona Rural, Manaus, AM, Brazil. \\ ${ }^{3}$ Instituto de Ciências Exatas e Tecnologia, Universidade Federal do Amazonas, Rua Nossa Senhora do Rosário, 3863, CEP \\ 69103-128, Tiradentes, Itacoatiara, AM, Brazil. \\ ${ }^{4}$ Departamento de Entomologia e Acarologia; Escola Superior de Agricultura "Luiz de Queiroz”, Universidade de São \\ Paulo; Avenida Pádua Dias, 11;13418-900, Piracicaba- SP, Brazil; CNPq Researcher.
}

\begin{abstract}
The African oil palm, Elaeis guineensis Jacq., is the second oil producing plant most extensively cultivated worldwide. The American oil palm, Elaeis oleifera (Kunth) Cortés, is a similar species rarely planted for commercial oil production, but often used for the production of hybrids with the African oil palm. The objective of this work was to compare the mite fauna of different genotypes of the African and the American oil palms as well as of their hybrids. In total, three and five genotypes of the African and the American oil palms and two of their hybrids available at an experiment station in the central part of the Brazilian Amazonia (Campo Experimental Rio Urubu, Embrapa Amazônia Ocidental, Rio Preto da Eva, Amazonas State) were evaluated. Samples were collected in the wet (May 2012) and the dry (October, November 2013) seasons. On American oil palms, mite density was much higher in the wet than in the dry season, while on palms of other groups no significant differences were observed between seasons. Phytophagous mites corresponded to $91.1 \%$ of all mites found and Eriophyoidea was by far the most abundant group of these mites. Plant damage by this and other mite groups was not noticed. Mites of the family Tenuipalpidae, to which Raoiella indica Hirst belongs, were not found in this study. In previous studies, $R$. indica was reported to cause severe damage to several plant species. Phytoseiid species richness and diversities were also higher in the American oil palms than on palms of other groups. The phytoseiids Amblyseius perditus Chant \& Baker and Iphiseiodes kamahorae De Leon were the most abundant predators, the first almost exclusively on BR 174 and Coari, and the second, on Manicoré genotypes of the American oil palms. Phytoseiid diversity on hybrids was as low as on African oil palm genotypes in the dry season and lower than on other palm groups in the wet season.
\end{abstract}

Key words: Biodiversity, Biological control, Ecology, Phytophagous mites, Phytoseidae, Raoiella indica

\section{Introduction}

Elaeis species and their hybrids are known as oil palms. The African oil palm, Elaeis guineensis Jacq., is second only to soybean in the worldwide vegetable oil production. It is extensively cultivated in Africa, America and Asia (Henderson \& Osborne 2000; Wahid et al. 2005). In Brazil, it is mostly cultivated in Bahia and Pará states.

The American oil palm, Elaeis oleifera (Kunth) Cortés, is found naturally from southern Mexico to the east region of the Brazilian Amazonas state. It is usually not cultivated for oil production, but it is widely used to generate hybrids in crosses with the African oil palm, in research efforts to obtain 
resistance to pests, diseases and other stressing environmental factors (Barcelos et al. 2002; Cunha et al. 2012).

The main pests of oil palms in the Brazilian Amazonia are curculionid beetles (Brazilio et al. 2012). Phytophagous mites have also been reported from those plants in Brazil, but so far causing no major damage. Tetranychus palmarum Flechtmann \& Noronha (Tetranychidae) was described from Pará, where it was mentioned to cause minor damage to young African oil palms (Flechtmann \& Noronha 2011). Tetranychus mexicanus (McGregor) and Brevipalpus phoenicis (Geijskes) (Tenuipalpidae) were also reported from the same host in the same state (Santana \& Flechtmann 1998), while Notostrix nasutiformes Gondim Jr., Flechtmann \& Moraes (Eriophyidae) was reported in northern and southeastern Brazil (Gondim Jr. et al. 2000). Propilus tavaresi Navia \& Flechtmann (Eriophyoidea: Phytoptidae), described from the Brazilian Amazonas state, was the only mite species reported so far from American oil palms, causing no noticeable damage (Navia \& Flechtmann 2005).

The red palm mite, Raoiella indica Hirst (Tenuipalpidae), has been mentioned in the Western Hemisphere as an important pest of several palm species, especially coconut (Cocos nucifera L.) (Carrillo et al. 2012a). Oil palm has been reported to allow the reproduction of $R$. indica (Welbourn 2009 apud Carrillo et al. 2012a), but Carrillo et al. (2012a) did not find it on oil palms in surveys conducted in botanic gardens of Florida, USA and Trinidad island, where the mite was present on several other palm species. It was recently reported from African oil palms in the Amazonian state of Roraima (Gondim Jr. et al. 2012; Navia et al. 2013), although nothing was mentioned about its effect on that host.

Previous characterization of the local fauna is considered essential for the success of biological control programs of pest organisms in a given region (Gondim Jr. et al. 2012), to evaluate the chances of effective control by locally prevailing natural enemies or the convenience for introduction of potentially more effective natural enemies (classic biological control). Scientific investigations have been conducted in Brazil on the possibility to control $R$. indica on coconut biologically, including evaluation of prospective native natural enemies (Gondim Jr. et al. 2012) and experimental introduction of exogenous natural enemies (Domingos et al. 2013).

Worldwide, little is known about predatory mites on oil palms. The objective of this work was to evaluate the mite fauna on American and African oil palms as well as in some of their hybrids, available in a genotype collection in the central part of the Brazilian Amazon. It could be hypothesized that American oil palms hosted higher mite diversity than African oil palms or their hybrids in the Amazon region, because of the Neotropical origin of the first palms.

\section{Material and Methods}

Samplings were conducted between October 30 and November 15, 2012 (dry season) and between May 14 and 23, 2013 (wet season), in an experiment station in a region with minimum disturbance of the Amazon Forest (CERU: Campo Experimental Rio Urubu; 02 26'04” S; 59³3'46” W; Embrapa Amazônia Ocidental; Rio Preto da Eva). This station is located about $140 \mathrm{~km}$ from Manaus and $54 \mathrm{~km}$ from Rio Preto da Eva.

Samples were taken from plots of genotypes of three groups of oil palms (in parentheses, the approximate area of each plot in ha): American oil palm [Autazes (1.6), BR 174 (1.6), Coari (3.6), Manicoré (7.5) and Moura (1.7)]; African oil palm [Bahia (8.8), Dabou (1.8) and Yangambi (1.3)]; and interspecific hybrids of those two species [BRS Manicoré (5.7) and Tonantins (0.6)]. In each plot, plants were distributed in a $9 \times 9 \times 9$ m quincunx pattern, corresponding to a density of 143 plants/ ha. Plant ages ranged between 5 and 15 years. The palms never received any application of 
pesticides for pest or pathogen control; weeds were regularly controlled manually and, sporadically, with herbicides; fertilizers (NPK, micronutrients) and lime were also sporadically used.

Leaflet samples were taken at each sampling date from five random palm trees of each genotype. Each sample consisted of ten leaflets from each of the basal, median and apical thirds of a leaf of the median crown stratum of a selected palm. Each sample was put in a paper bag, in turn put in a plastic bag, and then stored in a cool box to maintain the temperature slightly below $25^{\circ} \mathrm{C}$ for transport to the laboratory. The samples were kept in a refrigerator, at about $10^{\circ} \mathrm{C}$, for at most five days, until examined under a stereomicroscope for counting and collecting the mites.

The mites were recorded within each of the following taxonomic levels: Eriophyoidea, Eupodidae, Stigmaeidae, Tarsonemidae, Tenuipalpidae, Tetranychidae, Tydeoidea, Mesostigmata, Astigmatina and other Oribatida. Mite density per $\mathrm{cm}^{2}$ of leaf area was estimated by drawing the periphery of the leaflet onto a piece of paper of known weight/ area and then extrapolating for the weight of the piece of paper corresponding to the delimited leaflet.

After counting, the collected mites were mounted in Hoyer's medium for identification at lower taxonomic levels; the following proportions of the mites collected were mounted: Mesostigmata, $100 \%$; Cunaxidae and Stigmaeidae, about 30\%; Tetranychidae, about 20\%; Eriophyoidea, about 5\%. The following mite groups were additionally identified at least to genus level: Ascidae, Cunaxidae, Eriophyoidea (Eriophyidae and Phytoptidae), Phytoseiidae, Stigmaeidae and Tetranychidae.

Identification was done with the use of a phase contrast microscope (Leica, DMLB). Families were identified based on Krantz and Walter (2009), whereas genera were identified based on unpublished keys used in the Acarology Summer Program of the Ohio State University, USA. Species identification was based on the respective original descriptions and redescriptions, as listed in Skvarla et al. (2014), Moraes et al. (2016), Den Heyer and Hernandes (2017) and Demite et al. (2018).

In the presentation of the taxa collected, the mites were classified in three guilds, namely phytophagous, predatory and of other feeding habits. That was done to express the main feeding habit of the mite groups, although some taxa within certain groups (mainly tarsonemids and some Mesostigmata) are known to have other feeding habits than the ones in which they were classified (Krantz \& Walter 2009).

\section{Climatic data}

Climatic data were obtained from CERU weather station. The average temperature and $\mathrm{RH}$, and the total rainfall for the period of 30 days preceding the sampling dates were respectively $26.8 \pm 3.9$ ${ }^{\circ} \mathrm{C}, 84.0 \pm 17.0 \%$ and $97.0 \pm 1.5 \mathrm{~mm}$ in the dry season, and $25.3 \pm 2.6{ }^{\circ} \mathrm{C}, 91.0 \pm 11.0 \%$ and $391.8 \pm 10.7$ $\mathrm{mm}$ in the wet season. Average annual temperature and relative humidity and total annual rainfall at the weather station were $25.6 \pm 0.2^{\circ} \mathrm{C}, 87.7 \pm 0.7 \% \mathrm{RH}$ and $2,278 \pm 36.9 \mathrm{~mm}$ for 2012 and $25.6 \pm 0.1^{\circ} \mathrm{C}$, $88.7 \pm 0.7 \% \mathrm{RH}$ and $2,614 \pm 24.8 \mathrm{~mm}$ in 2013 .

\section{Statistical analysis}

The average numbers of mites per group of 30 leaflets (taken from each plant) were calculated. For normalization, the data were transformed to $\log (\mathrm{x}+10)$ (for a combination of all mites), $\log (\mathrm{x}-$ 1) and $\log (x+1)$ (for phytoseiids found respectively on African and American oil palms). Normalization was confirmed by at least one of the following tests: Kolmogorov-Smirnov, Lilliefors or Shapiro-Wilk; homocedacity was confirmed by Levene test. Univariate ANOVA was done to compare the average numbers of combined group of mites $/ 30$ leaflets and the average numbers of phytoseiid mites/30 leaflets between each oil palm groups (Brazilian, African and hybrid) and between dry and wet seasons. These average numbers were compared by Unequal N HSD test, at $5 \%$ significance. The analyses were run in Statistica program, version 12 (Statsoft 2015). Calculations of Shannon-Wiener $(\mathrm{H})$ diversity indexes were done using $\mathrm{R}$ program version 3.1.2 (R Core Team 2015). 


\section{Results}

\section{Comparisons between palm groups and seasons}

All mites

In total, 38,152 mites were counted, of which 34,411 (688 mites/ 30 leaflets) on American oil palms (Table 1), 2,028 (68 mites/ 30 leaflets) on African oil palms (Table 2) and 1,713 (86 mites/ 30 leaflets) on hybrids (Table 3). These belonged respectively to 33, 17 and 17 mite species. The average areas of 30 leaflets taken from each palm of each of those palm groups were respectively $6,308,3,571$ and $5,028 \mathrm{~cm}^{2}$. Thus, the corresponding average mite densities and species were respectively $0.1,0.02$ and 0.02 mite and $0.005,0.005$ and 0.003 mite species per $\mathrm{cm}^{2}$.

On American oil palms, 93.1\% of the mites were found in the wet season, density being significantly higher in this than in the dry season (respectively 1,281.0 and 95.2 mites/ 30 leaflets; $\mathrm{t}=-6.4721 ; \mathrm{df}=48 ; \mathrm{p}<0.0001$ ) (Figure 1). On African oil palms, $70.5 \%$ of the mites were found in the dry season, but because of the high variation, densities were not statistically different between seasons (respectively 95.3 and 39.9 mites/ 30 leaflets; $\mathrm{t}=1.6441, \mathrm{df}=28, \mathrm{p}=0,111$ ). On hybrids, mites were found at similar proportions in both seasons, respectively 50.3 and $49.7 \%$ in the dry and wet seasons. The corresponding mite densities (respectively 86.1 and 85.1 mites/ 30 leaflets in the dry and wet seasons) were not statistically different $(\mathrm{t}=0.0948, \mathrm{df}=18, \mathrm{p}=0.9255)$.

In the wet season, mite density was significantly higher on American oil palms than in palms of other groups $(\mathrm{n}=50, \mathrm{~F}=31.6407, \mathrm{p}<0.0001)$, while the difference between densities on African oil palms and on hybrids was not statistically significant $(n=50, F=0.1856, p=0.4685)$ (Figure 1). In the dry season, differences in mite densities among palm groups were also not statistically significant $(\mathrm{n}=50, \mathrm{~F}=0.0214, \mathrm{p}=0.9788)$.

\section{Phytophagous mites}

In total, 34,728 phytophagous mites were found, corresponding to $91.1 \%$ of all mites (Tables 1 -3), but damage caused by them was not noticeable. They belonged to the superfamily Eriophyoidea (Eriophyidae and Phytoptidae), and to the families Tarsonemidae and Tetranychidae. The vast majority $(90.8 \%)$ was found in the wet season. The most abundant phytophagous group was by far the Eriophyoidea, represented by 33,732 specimens ( $97.1 \%$ of all phytophagous mites). In samples in which males were present, the tetranychids were identified as T. palmarum.

On American oil palms, $92.9 \%$ of the mites collected were phytophagous, and $97.7 \%$ of these were Eriophyoidea (Table 1), of which 96.7\% $(30,199)$ were found in the wet season. On African oil palms, a much lower proportion $(65.1 \%)$ of the mites were phytophagous; $80.6 \%$ of these were Eriophyoidea (Table 2), of which $78 \%(1,030)$ were found in the dry season. On hybrids, the proportion of phytophagous mites (84.4\%) was intermediate to proportions on American and African oil palms; they were found in similar proportions in the dry and wet seasons (respectively 46 and $54 \%, 665$ and 781 specimens). About $98.7 \%$ of these were Eriophyoidea (Table 3).

\section{Predatory mites}

In total, 1,470 predatory mites were found, corresponding to $3.8 \%$ of all mites and belonging to the families Ascidae, Cheyletidae, Cunaxidae, Iolinidae, Phytoseiidae and Stigmaeidae (Tables 1$3)$. As the phytophagous mites, the majority of the predators $(62.6 \%)$ was found in the wet season. The most abundant families were Phytoseiidae (57\% of all predators) and Cunaxidae (29.5\%). On American oil palms, predatory mites accounted for $3.5 \%$ of the mites collected; $61.4 \%$ of them were phytoseiids, and $31.2 \%$ were cunaxids (Table 1). On African oil palms, $9.8 \%$ of the mites found were predators, of which the phytoseiids corresponded to $41.9 \%$, followed by the iolinids (35.6\%) (Table 2 ). On hybrids, $4.2 \%$ of the mites found were predators; rather differently from palms of other groups, the phytoseiids were only $25.0 \%$ of the predators, while the cunaxids were $40.3 \%$ and the iolinids $22.2 \%$ (Table 3 ). 
TABLE 1. Numbers of mites/30 leaflets of five genotypes of American oil palms (Elaeis oleifera) at CERU (Campo Experimental Rio Urubu; Embrapa Amazônia Ocidental) experiment station, at Rio Preto da Eva, Amazonas state, Brazil, in samples collected between October 30 and November 15, 2012 (dry season) and between May 14 and 23, 2013 (wet season).

\begin{tabular}{|c|c|c|c|c|c|c|c|c|c|c|c|c|c|}
\hline \multirow[t]{2}{*}{ Family/Species } & \multicolumn{2}{|c|}{ Autazes } & \multicolumn{2}{|c|}{ BR 174} & \multicolumn{2}{|c|}{ Coari } & \multicolumn{2}{|c|}{ Manicoré } & \multicolumn{2}{|c|}{ Moura } & \multicolumn{3}{|c|}{ Total } \\
\hline & Dry & Wet & Dry & Wet & Dry & Wet & Dry & Wet & Dry & Wet & Number & & $\%$ \\
\hline Phytophagous groups & 83 & 6,977 & 488 & 11,569 & 14 & 4,901 & 474 & 4,503 & 450 & 2,502 & 31,961 & 92.9 & \\
\hline Eriophyidae & 50 & 6,964 & 444 & 11,528 & - & 3,264 & 106 & 4,419 & 441 & 2,392 & 29,608 & 92,6 & \\
\hline Nasuchus sp. nov. & 50 & 3,482 & & 5,764 & & 1,632 & & 2.210 & & 1,196 & 14,334 & & 48.4 \\
\hline Notostrix $\mathbf{s p .}$ nov.1 & & 3,482 & 444 & 5,764 & & 1,632 & 106 & 2.209 & 441 & 1,196 & 15,274 & & 51.6 \\
\hline Phytoptidae & - & - & - & - & - & 1,632 & - & - & - & - & 1,632 & 5.1 & \\
\hline Propilus sp. nov. & & & & & & 1,632 & & & & & 1,632 & & 100.0 \\
\hline Tarsonemidae $^{1}$ & 7 & 5 & 32 & 31 & 3 & 5 & 65 & 82 & - & 101 & 331 & 1.0 & \\
\hline Tetranychidae & 26 & 8 & 12 & 10 & 11 & - & 303 & 2 & 9 & 9 & 390 & 1.3 & \\
\hline Predatory groups & 54 & 53 & 27 & 262 & 20 & 281 & 194 & 77 & 64 & 168 & 1,200 & 3.5 & \\
\hline Ascidae & - & - & - & 4 & - & - & - & - & - & 2 & 6 & 0.5 & \\
\hline Asca spp. & & & & 4 & & & & & & 2 & 6 & & 100.0 \\
\hline Cunaxidae & 17 & 25 & 2 & 73 & 8 & 146 & 11 & 33 & 13 & 46 & 374 & 31.2 & \\
\hline Armascirus.sp. nov. & & & & & & & 5 & 2 & & & 7 & & 1.9 \\
\hline Scutopalus sp. nov.1 & 17 & 25 & 2 & 64 & 8 & 137 & 6 & 31 & 13 & 40 & 343 & & 91.7 \\
\hline Scutopalus sp. nov. 2 & & & & 9 & & 9 & & & & 6 & 24 & & 6.4 \\
\hline Iolinidae & - & - & - & 6 & - & - & 18 & - & 2 & - & 26 & 2.2 & \\
\hline Phytoseiidae & 25 & 19 & 25 & 172 & 11 & 135 & 165 & 43 & 22 & 120 & 737 & 61.4 & \\
\hline $\begin{array}{l}\text { Amblydromalus zannoui Sourassou, } \\
\text { Sarmento \& Moraes }\end{array}$ & 1 & 1 & & & & 6 & & 2 & & 14 & 24 & & 6.1 \\
\hline Amblyseius aerialis (Muma) & & 1 & 2 & 1 & & 4 & 5 & 1 & 1 & & 15 & & 3.8 \\
\hline Amblyseius herbicolus (Chant) & & 1 & & & & & & & & & 1 & & 0.3 \\
\hline $\begin{array}{l}\text { Amblyseius aff. lunatus (Denmark \& } \\
\text { Evans) }\end{array}$ & 1 & 2 & & 13 & & 4 & & 5 & & 12 & 37 & & 9.4 \\
\hline Amblyseius perditus Chant \& Baker & & & & 51 & 2 & 40 & & & 2 & & 95 & & 24.2 \\
\hline Amblyseius vasiformis Moraes \& Mesa & 1 & & 2 & 3 & 4 & & 28 & 7 & 1 & & 46 & & 11.7 \\
\hline $\begin{array}{l}\text { Arrenoseius urquharti (Yoshida-Shaul } \\
\text { \& Chant) }\end{array}$ & & & & 1 & & & & & & & 1 & & 0.3 \\
\hline $\begin{array}{l}\text { Amazoniaseius imparisetosus sp. nov., } \\
\text { gen. nov. (Demite, Cruz \& McMurtry) }\end{array}$ & & & & 1 & & 1 & & & & & 2 & & 0.5 \\
\hline Iphiseiodes kamahorae De Leon & & 1 & & & 2 & & 53 & 13 & 3 & & 72 & & 18.4 \\
\hline Iphiseiodes sp. nov. & & & & & & & & & & 15 & 15 & & 3.8 \\
\hline Iphiseiodes zuluagai Denmark \& Muma & 7 & 2 & 5 & 4 & & 3 & 15 & & 1 & 9 & 46 & & 11.7 \\
\hline Neoseiulus barkeri Hughes & & & & & & 4 & & & & 1 & 5 & & 1.3 \\
\hline Proprioseiopsis neotropicus (Ehara) & 1 & & & 12 & & & 2 & & & 1 & 16 & & 4.1 \\
\hline Phytoscutus sexpilis Muma & & & 2 & & & & & & & & 2 & & 0.5 \\
\hline $\begin{array}{l}\text { Phytoscutus moraesi sp. nov. Demite, } \\
\text { Cruz \& Cavalcante }\end{array}$ & & & & & & & & 2 & & & 2 & & 0.5 \\
\hline $\begin{array}{l}\text { Typhlodromips angustus Guanilo \& } \\
\text { Moraes }\end{array}$ & & & & & & & & & 1 & & 1 & & 0.3 \\
\hline $\begin{array}{l}\text { Typhlodromus (Anthoseius) } \\
\text { transvaalensis (Nesbitt) }\end{array}$ & & 1 & & 6 & & 1 & & 2 & & 2 & 12 & & 3.1 \\
\hline Inmatures & 6 & 6 & 7 & 40 & 3 & 36 & 46 & 6 & 11 & 29 & 190 & & - \\
\hline Males & 8 & 4 & 7 & 40 & & 36 & 16 & 5 & 2 & 37 & 155 & & - \\
\hline Stigmaeidae & 12 & 9 & - & 7 & 1 & - & - & 1 & 27 & - & 57 & 4.7 & \\
\hline $\begin{array}{l}\text { Agistemus rodriguezi sp. nov. Paktinat- } \\
\text { Saeij \& Cruz }\end{array}$ & 12 & 9 & & 7 & 1 & & & 1 & 27 & & 57 & & 100.0 \\
\hline Other feeding habits & 46 & 38 & 76 & 273 & 94 & 101 & 237 & 118 & 60 & 207 & 1,250 & 3.6 & \\
\hline Astigmatina & - & 18 & 55 & 13 & 1 & 2 & 31 & 64 & 9 & 35 & 228 & 18.2 & \\
\hline Other Oribatida & 8 & 3 & 10 & 31 & 22 & 1 & 158 & 18 & 9 & 1 & 261 & 1.3 & \\
\hline Eupodidae & - & - & - & - & - & - & 12 & 1 & 2 & - & 15 & 20.9 & \\
\hline Tydeidae & & 3 & 11 & 6 & 71 & 75 & 36 & 27 & 40 & 24 & 293 & 23.4 & \\
\hline Triophtydeidae & 38 & 14 & - & 223 & - & 23 & - & 8 & - & 147 & 453 & 36.2 & \\
\hline Total & 183 & 7,068 & 590 & 12,104 & 129 & 5,283 & 905 & 4,698 & 574 & 2,877 & $34,411^{2}$ & 100.0 & \\
\hline
\end{tabular}

${ }^{1}$ Including other non-parasitic habits.

${ }^{2}$ The numbers in this table were extrapolated from the number of mites counted for each family and the proportion of genus/ species identified after mounting samples of each family, as indicated in "Material(s) and Methods 
TABLE 2. Numbers of mites/30 leaflets of three genotypes of African oil palms (Elaeis guineensis) at CERU (Campo Experimental Rio Urubu; Embrapa Amazônia Ocidental) experiment station, at Rio Preto da Eva, Amazonas state, Brazil, in samples collected between October 30 and November 15, 2012 (dry season) and between May 14 and 23, 2013 (wet season).

\begin{tabular}{|c|c|c|c|c|c|c|c|c|c|}
\hline \multirow{2}{*}{ Family/Species } & \multicolumn{2}{|c|}{ Bahia } & \multicolumn{2}{|c|}{ Dabou } & \multicolumn{2}{|c|}{ Yangambi } & \multicolumn{2}{|c|}{ Total } & \\
\hline & Dry & Wet & Dry & Wet & Dry & Wet & Number & $\%$ & \\
\hline Phytophagous groups & 349 & 230 & 588 & 1 & 93 & 60 & 1,321 & 65.1 & \\
\hline Eriophyidae & 334 & 69 & 585 & - & 55 & 22 & 1,065 & 80,6 & \\
\hline Notostrix $\mathbf{s p .}$ nov.2 & 334 & 69 & 585 & & 55 & 22 & 1,065 & & 100.0 \\
\hline Tarsonemidae $^{1}$ & 2 & 62 & - & - & 2 & 17 & 83 & 6.3 & \\
\hline Tetranychidae & 13 & 99 & 3 & 1 & 36 & 21 & 173 & 13.1 & \\
\hline Predatory groups & 4 & 13 & 14 & 9 & 123 & 34 & 198 & 9.8 & \\
\hline Ascidae & - & 1 & - & - & - & 1 & 2 & 1.0 & \\
\hline Asca spp. & & 1 & & & & 1 & 2 & & 100.0 \\
\hline Cunaxidae & - & 2 & 2 & 4 & 11 & 11 & 30 & 15.2 & \\
\hline Scutopalus sp. nov.1 & & 2 & 2 & 4 & 11 & 11 & 30 & & 100.0 \\
\hline Iolinidae & - & - & 5 & - & 61 & 4 & 70 & 35.3 & \\
\hline Phytoseiidae & 3 & 10 & 5 & 1 & 51 & 13 & 83 & 41.9 & \\
\hline $\begin{array}{l}\text { Amblydromalus zannoui Sourassou } \\
\text { et al. }\end{array}$ & & & 2 & & 5 & 2 & 9 & & 25.7 \\
\hline Amblyseius aerialis (Muma) & & & & & & 3 & 3 & & 8.6 \\
\hline Amblyseius perditus Chant \& Baker & & & & & 1 & 2 & 3 & & 8.6 \\
\hline $\begin{array}{l}\text { Amblyseius vasiformis Moraes \& } \\
\text { Mesa }\end{array}$ & & & & & & 1 & 1 & & 2.9 \\
\hline $\begin{array}{l}\text { Iphiseiodes zuluagai Denmark \& } \\
\text { Muma }\end{array}$ & 3 & 2 & 2 & 1 & 8 & 1 & 17 & & 48.6 \\
\hline Proprioseiopsis cannaensis (Muma) & & 1 & & & 1 & & 2 & & 5.7 \\
\hline Inmatures & & 6 & 1 & & 27 & 2 & 36 & & - \\
\hline Males & & 1 & & & 9 & 2 & 12 & & - \\
\hline Stigmaeidae & 2 & - & 2 & 4 & - & 5 & 13 & 6.6 & \\
\hline Agistemus sp. nov. & 2 & & 2 & 4 & & 5 & 13 & & 100.0 \\
\hline Other feeding habits & 214 & 195 & 16 & 8 & 27 & 49 & 509 & 25.1 & \\
\hline Astigmatina & 8 & 186 & 11 & 1 & 1 & 44 & 251 & 49.3 & \\
\hline Other Oribatida & 4 & 3 & - & 6 & 14 & - & 27 & 5.3 & \\
\hline Tydeidae & 200 & 6 & - & 1 & 8 & 5 & 220 & 43.2 & \\
\hline Triophtydeidae & 2 & - & 5 & - & 4 & - & 11 & 2.2 & \\
\hline Total & 569 & 438 & 618 & 18 & 242 & 143 & 2,028 & 100.0 & \\
\hline
\end{tabular}

${ }^{1}$ Including other non-parasitic habits.

${ }^{2}$ The numbers in this table were extrapolated from the number of mites counted for each family and the proportion of genus/ species identified after mounting samples of each family, as indicated in "Material(s) and Methods

On American oil palms, 737 phytoseiids were found, belonging to 17 species of 10 genera (Table 1). The most diverse genera were Amblyseius Berlese (five species), followed by Iphiseiodes De Leon (three) and Phytoscutus Muma (two) (Table 1). The most abundant species were Amblyseius perditus Chant \& Baker and Iphiseiodes kamahorae De Leon, accounting for 24.2 and $18.4 \%$ of the phytoseiids on this palm group. A new genus (Amazoniaseius Demite, Cruz \& McMurtry) and three new phytoseiid species Amazoniaseius imparisetosus Demite, Cruz \& McMurtry (Demite et al. 2017), Iphiseiodes sp. nov. and Phytoscutus moraesi sp. nov. Demite, Cruz \& Cavalcante (Demite et al. 2019), were found on these plants (Table 1). Phytoseiid densities on 
these palms were not significantly different between seasons (respectively 9.8 and 14.0 mites/ 30 leaflets in the dry and wet seasons; $\mathrm{t}=-0.7865, \mathrm{df}=48, \mathrm{p}=0.4354$ ) (Figure 2).

On African oil palms, only 83 phytoseiids of six species of four genera were found (Table 2). On these palms, Amblyseius was the most diverse genus, with three species; each of the other genera were represented by a single species. The most abundant species were Iphiseiodes zuluagai Denmark \& Muma and Amblydromalus zannoui Sourassou, Sarmento \& Moraes, representing respectively 48.6 and $25.7 \%$ of the phytoseiids. Also on palms of this group, the phytoseiid densities were not statistically different between seasons (respectively 0.9 and 1.6 mite/ 30 leaflets in the dry and wet seasons; $\mathrm{t}=-1.5130, \mathrm{df}=28, \mathrm{p}=0.1414$ ) (Figure 2).

TABLE 3. Numbers of mites/30 leaflets of two interspecific hybrids of African and American oil palms (Elaeis guineensis x Elaeis oleifera) at CERU (Campo Experimental Rio Urubu; Embrapa Amazônia Ocidental) experiment station, at Rio Preto da Eva, Amazonas state, Brazil, in samples collected between October 30 and November 15, 2012 (dry season) and between May 14 and 23, 2013 (wet season).

\begin{tabular}{|c|c|c|c|c|c|c|c|}
\hline \multirow{2}{*}{ Family/Species } & \multicolumn{2}{|c|}{ BRS Manicoré } & \multicolumn{2}{|c|}{ HIE Tonantins } & \multicolumn{3}{|c|}{ Total } \\
\hline & Dry & Wet & Dry & Wet & Number & & $\%$ \\
\hline Phytophagous groups & 596 & 112 & 69 & 669 & 1,446 & 84.4 & \\
\hline Eriophyidae & 295 & 54 & 34 & 331 & 714 & 49.4 & \\
\hline Notostrix sp.nov.1 & 295 & 54 & 34 & 331 & 714 & & 100.0 \\
\hline Phytoptidae & 295 & 54 & 33 & 331 & 713 & 49.3 & \\
\hline Propilus sp. nov. & 295 & 54 & 33 & 331 & 713 & & 100.0 \\
\hline Tarsonemidae $^{1}$ & 6 & 3 & 2 & 7 & 18 & 1.2 & \\
\hline Tetranychidae & - & 1 & - & - & 1 & 0.1 & \\
\hline Predatory groups & 44 & 11 & 6 & 11 & 72 & 4.2 & \\
\hline Ascidae & 1 & 3 & - & - & 4 & 5.6 & \\
\hline Asca spp. & 1 & 3 & & & 4 & & 100.0 \\
\hline Cheyletidae & & & & 1 & 1 & 1.4 & \\
\hline Cunaxidae & 18 & 4 & 3 & 4 & 29 & 40.3 & \\
\hline Scutopalus sp. nov.1 & 18 & 4 & 3 & 4 & 29 & & 100.0 \\
\hline Iolinidae & 16 & - & - & - & 16 & 22.2 & \\
\hline Phytoseiidae & 9 & - & 3 & 6 & 18 & 25.0 & \\
\hline Amblyseius aerialis (Muma) & 1 & & & & 1 & & 11.1 \\
\hline Amblyseius perditus Chant \& Baker & 1 & & 1 & & 2 & & 22.2 \\
\hline Iphiseiodes zuluagai Denmark \& Muma & 3 & & & 3 & 6 & & 66.7 \\
\hline Inmatures & 3 & & 2 & 1 & 6 & & - \\
\hline Males & 1 & & & 2 & 3 & & - \\
\hline Stigmaeidae & - & 4 & - & - & 4 & 5.4 & \\
\hline Agistemus sp.nov. & & 4 & & & 4 & & 100.0 \\
\hline Other feeding habits & 96 & 4 & 40 & 55 & 195 & 11.4 & \\
\hline Astigmatina & - & 1 & & 42 & 43 & 22.1 & \\
\hline Other Oribatida & 12 & 1 & 2 & 2 & 17 & 8.7 & \\
\hline Eupodidae & 1 & - & - & - & 1 & 0.5 & \\
\hline Tydeidae & 83 & 2 & - & - & 85 & 43.6 & \\
\hline Triophtydeidae & - & - & 38 & 11 & 49 & 25.1 & \\
\hline Total & 736 & 127 & 115 & 735 & 1,713 & 100.0 & \\
\hline
\end{tabular}

${ }^{1}$ Including other non-parasitic habits.

${ }^{2}$ The numbers in this table were extrapolated from the number of mites counted for each family and the proportion of genus/ species identified after mounting samples of each family, as indicated in "Material(s) and Methods 
TABLE 4. Species richness and Shannon-Wiener diversity indexes of phytoseiid mites in the dry (October/ November) and wet (May) seasons on accessions of oil palms at CERU (Campo Experimental Rio Urubu; Embrapa Amazonia Ocidental) experiment station, Rio Preto da Eva, Amazonas state.

\begin{tabular}{lcccc}
\hline \multirow{2}{*}{ Plant } & \multicolumn{2}{c}{ Species richness } & \multicolumn{2}{c}{ Shannon-Wiener index (H) } \\
& Dry & Wet & Dry & Wet \\
\hline American oil palms (Elaeis oleifera) & 10 & 15 & 1.54 & 2.11 \\
Autazes & 5 & 7 & 1.16 & 1.89 \\
BR 174 & 4 & 9 & 1.29 & 1.04 \\
Coari & 3 & 7 & 1.20 & 1.25 \\
Manicoré & 5 & 7 & 1.68 & 1.62 \\
Moura & 6 & 7 & 0.96 & 1.61 \\
African oil palms (Elaeis guineensis) & 4 & 6 & 0.0 & 0.64 \\
Bahia & 1 & 2 & 0.70 & 0.0 \\
Dabou & 1 & 1 & 1.06 & 1.52 \\
Yangambi & 4 & 5 & 1.01 & 0.0 \\
Hybrids (Elaeis guineensis x Elaeis oleifera) & 3 & 1 & 0.95 & 0.0 \\
BRS Manicoré & 3 & 0 & 0.0 & 0.0 \\
HIE Tonantins & 1 & 1 &
\end{tabular}

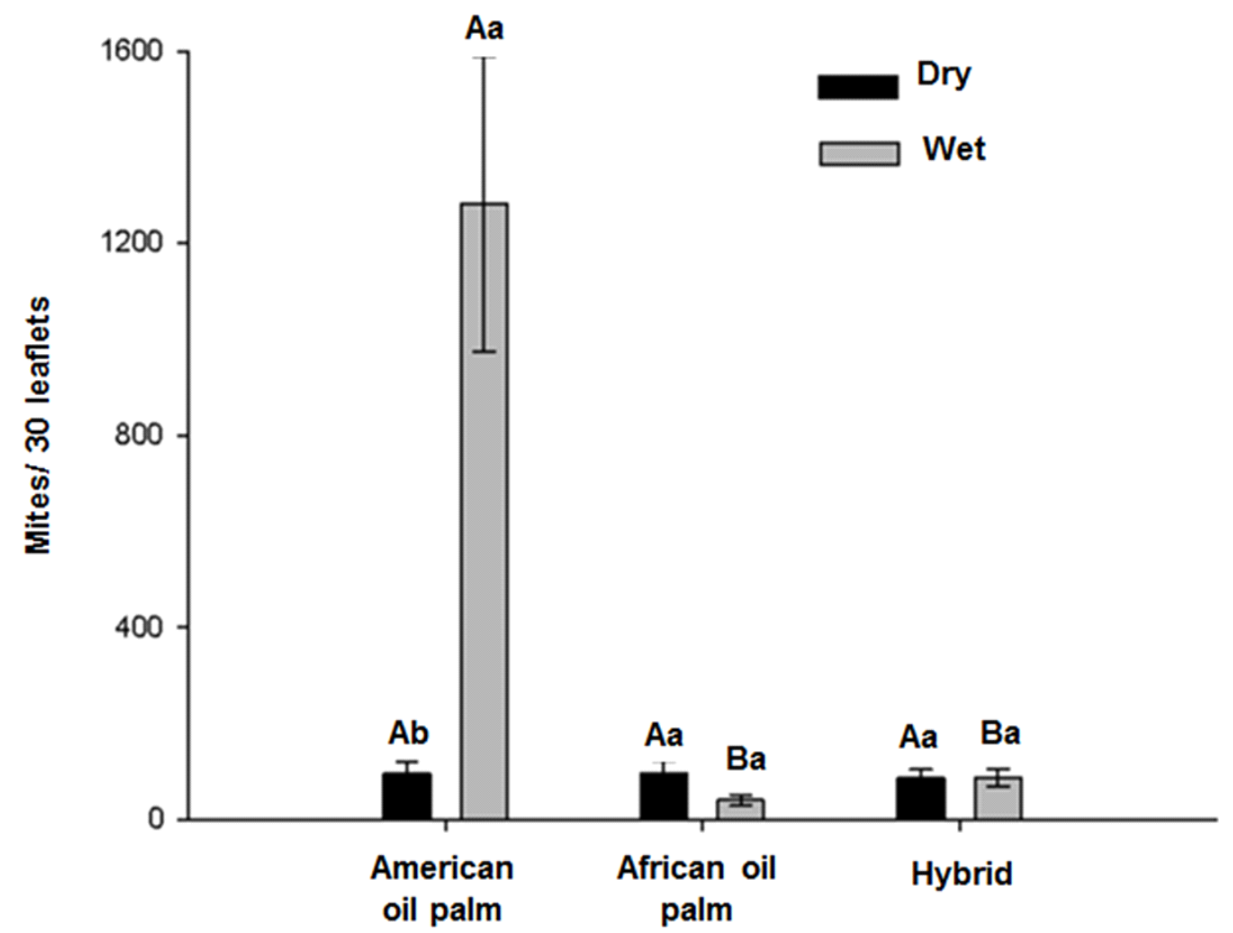

FIGURE 1. Combined mite densities (average \pm SE) in the dry (October/ November) and wet (May) seasons on oil palms. Different capital letters indicate significant differences between palm groups within each season, while different low case letters indicate significant differences between seasons within each palm group.

On hybrids, only 18 specimens of three species of two genera were found, two of Amblyseius and one of Iphiseiodes (Table 3). Thus, predator densities were very low (respectively 1.2 and 0.6 mites/ 30 leaflets in the dry and wet seasons), I. zuluagai being the most abundant, with only six 
specimens (Table 3). In the wet season, phytoseiids were found in only one of the ten palms examined. For this reason, statistical comparison of phytoseiid densities was not done between seasons.

Phytoseiid density was higher on American oil palms than on African oil palms in the wet $(\mathrm{n}=$ $40, \mathrm{~F}=13.9173, \mathrm{p}<0.001)$ and in the dry $(\mathrm{n}=40, \mathrm{~F}=11.4499, \mathrm{p}<0.0001)$ seasons (Figure 2). Because of the low numbers of phytoseiids on the hybrids, densities on these palms were not statistically compared with those of other palm groups.

Species richness and diversity were much higher on American oil palms than on palms of other groups (Table 4). On the different genotypes of American oil palms, the number of phytoseiid species varied from seven to nine in the wet and three to six in the dry seasons. On the different genotypes of African oil palms, the number of phytoseiid species varied from one to five in the wet and from one to four in the dry season. On hybrids, the numbers of species were very low (maximum of three) in both seasons.

The highest diversity indexes were observed on American oil palms both in wet (2.11) and dry (1.54) seasons (Table 4). Diversity was much lower on African oil palms and on hybrids in both seasons.

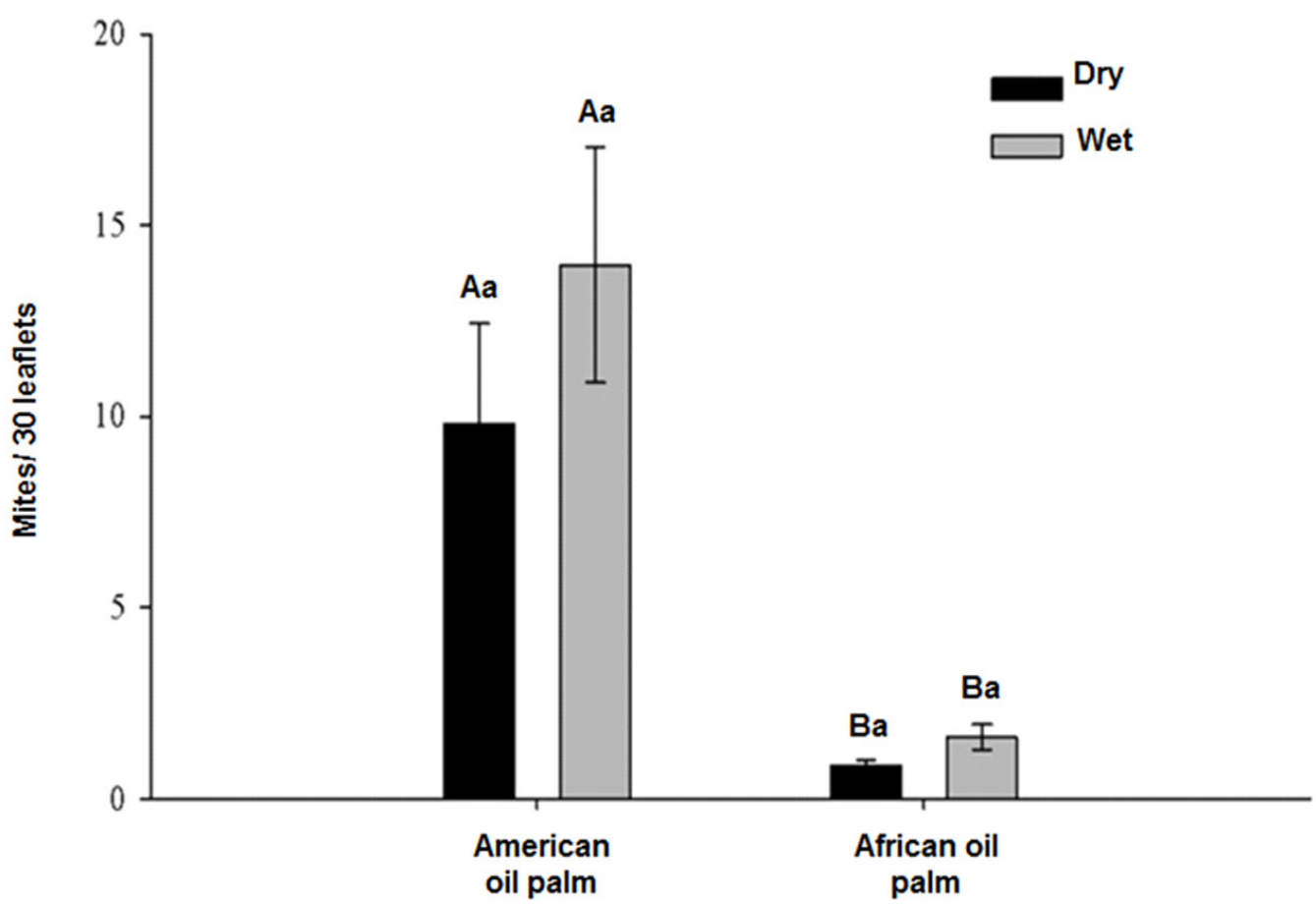

FIGURE 2. Phytoseiid densities (average \pm SE) in the dry (October/ November) and wet (May) seasons on oil palms. Different capital letters indicate significant differences between palm groups within each season, while different low case letters indicate significant differences between seasons within each palm group.

Mites of other feeding habits

On palms of the three groups, a total of 1,954 mites of other feeding habits was found, corresponding to $5.1 \%$ of all mites collected. About $53.6 \%$ of these were found in the wet and $46.4 \%$ in the dry season. The most abundant groups were Triophtydeidae, Tydeidae, Astigmatina and nonAstigmatina Oribatida. On American oil palms, Triophtydeidae and Tydeidae were the most abundant, corresponding respectively to 36.2 and $23.4 \%$ of the mites classified as of other feeding 
habits (Table 1). On African oil palms, Astigmatina and Tydeidae were the most abundant, corresponding to 49.3 and $43.2 \%$ of these mites of this group (Table 2). As on American oil palms, Triophtydeidae and Tydeidae and were the most abundant groups on hybrids, corresponding respectively to 25.1 and $43.6 \%$ of these mites (Table 3 ).

\section{Comparisons between palm genotypes}

None of the American genotypes had consistently highest or lowest numbers of phytophagous or predatory mites in both seasons, but mites of other feeding habits were consistently less numerous on 'Autazes'. Considerably lower numbers of mites in general were found on 'Autazes' and 'Coari' in the dry season, and on 'Moura' in the wet season, mostly because of the lower numbers of phytophagous mites on these genotypes in both seasons. The largest numbers of predatory mites were found on 'Manicoré' in the dry season, and on 'BR 174' and 'Coari' in the wet season.

On African oil palms, predatory mites (especially iolinids and phytoseiids) were most numerous on 'Yangambi' in both seasons. Mites of other feeding habits (non-phytophagous) were most numerous on 'Bahia'. None of the genotypes had consistently highest or lowest numbers of phytophagous mites. Almost no phytophagous mite was found on 'Dabou' in the wet season.

On hybrids while mites in general were most numerous on 'BRS Manicoré' in the dry season, they were most numerous on 'HIE Tonantins' in the wet season. None of the different hybrids had consistently highest or lowest numbers of mites of any feeding habit in both seasons.

\section{Discussion}

Densities of the pooled mites in this study were comparable to those reported by Cruz et al. (2015) for mites on coconut leaves in the same general area where the present study was conducted. In that study, densities ranged between 0.04 and 0.08 mites $/ \mathrm{cm}^{2}$. Prevalence of eriophyoids was also reported by those authors. However, the proportion of tetranychid mites in that study was considerably higher, reflecting the susceptibility of coconut to those mites, as reported by other authors (Rai et al. 1991; Lawson-Balagbo et al. 2008; Gondim Jr. et al. 2012).

The absence of noticeable mite damage in the present study is seemingly due to the low densities of these mites, whose numbers were high only because of the large sample sizes, which in one extreme reached a maximum average of over $6,000 \mathrm{~cm}^{2}$ per sample of American oil palm. Additionally, most eriophyoids found in this study belong to groups that have not been reported to cause severe damage to their hosts (Gondim Jr. et al. 2000; Navia \& Flechtmann 2005), namely to the genera Nasuchus Navia \& Flechtmann, Notostrix Keifer and Propilus Keifer (the first two Eriophyidae, and the third Phytoptidae). The prevalence of eriophyoids on oil palm in this work and on coconut in the work of Cruz et al. (2015) had not been reported in previous works conducted on coconut in Brazil (Lawson-Balagbo et al. 2008; Gondim Jr. et al. 2012; Oliveira et al. 2012). Although the specific reason for that difference could not be determined, differently from this work and that of Cruz et al. (2015), previous works were conducted in generally drier areas. Propilus tavaresi was the only eriophyoid species described so far from American oil palms (Navia \& Flechtmann 2005), but extensive mite surveys on this palm had not been previously conducted in Brazil.

The absence of tenuipalpid mites in this study contrasts with their reported presence on coconut by Cruz et al. (2015) and on oil palm by Santana and Flechtmann (1998). Raoiella indica is considered a threatening tenuipalpid to the production of coconut, banana and several ornamentals (most of which Arecaceae) in Brazil and elsewhere (Gondim Jr. et al. 2012). Despite the report of $R$. indica on African oil palms in the Amazonian state of Roraima by Gondim Jr. et al. (2012) and the 
fact that it has been reported from coconut in Manaus region (Rodrigues \& Antony 2011; Cruz et al. 2015), its absence in the present study most certainly relates to its absence in the region where this study was conducted. This area is located about $140 \mathrm{~km}$ away from the places where this mite was reported on coconut in Manaus. Cruz et al. (2015) also failed to find $R$. indica on coconut in the experiment station where the present study was conducted, in an enclave of the Amazon forest.

Despite the fact that none of the few studies conducted so far have indicated oil palms as suitable hosts for R. indica (Cocco \& Hoy 2009; Carrilo et al. 2012a; Hoy et al. 2012), it is still conceivable that this mite is able to cause significant damage to some of the genotypes, given their variability in suitability as hosts for other mites, observed in this study. Beard et al. (2012) studied the morphological characteristics of the stomata of arecaceous plants, relating them to the incidence of $R$. indica. As this mite feeds from cells within the stomata (Ochoa et al. 2011), potential hosts with somehow protected stomata are not expected to be severely affected (Beard et al. 2012). Peláez et al. (2010) reported differences between African and American oil palms and their hybrids in relation to stomatal densities and opening pattern. These differences might have important bearing on the suitability of the different genotypes to attack by $R$. indica. Those authors did not refer to the presence of any protective obstruction on the stomata of these palms that could prevent damage by the mite. Given the importance of $R$. indica as a pest of several arecaceous plants and the extent of the cultivation of oil palm in tropical areas, evaluation of the possible effect of this pest on different oil palm genotypes is warranted.

In relation to predators, phytoseiids were the most diverse and abundant among the predatory mites, consistent with previous studies across different ecosystems (McMurtry et al. 2013), including coconut in the Brazilian Amazonia (Cruz et al. 2015). In mite surveys conducted in different crops in other parts of Brazil, Stigmaeidae has often been shown as the second most abundant predatory mite family (Lawson-Balagbo et al. 2008; Gondim Jr. et al. 2012; Oliveira et al. 2012), but higher abundance of Cunaxidae than of Stigmaeidae, observed in the present study, was also reported by Cruz et al. (2015). In the work of Ferla and Moraes (2008), Cunaxidae was likewise the second most abundant predatory mite family on rubber trees in Pontes e Lacerda (Mato Grosso state), near the southeastern extreme of the Brazilian Amazonia. Conversely, in the examination of different host plants, including trees and other plant groups, in the coastal Atlantic Forest of São Paulo state (Castro \& Moraes 2007), Cunaxidae and Stigmaeidae occurred at approximately the same proportions. Conversely, in a similar study also conducted on rubber plant in Itiquira (Mato Grosso state), Stigmaeidae was the second most abundant family, with Cunaxidae coming in a distant third position (Demite et al. 2009). These results suggest cunaxids to be often numerous on palm plants, but not on other arboreal plants, in the Brazilian Amazon region.

The determined phytoseiid fauna was not compatible with that reported by Gondim Jr. et al. (2012) and Cruz et al. (2015). The most abundant species were A. largoensis in the first and $A$. aerialis in the second of those studies. Amblyseius largoensis has been the predator most often reported in association with $R$. indica worldwide (Carrillo et al. 2012b), and thus its efficiency as a predator of that pest has been studied under controlled conditions (Carrilo et al. 2011; Domingos et al. 2013; Carrillo et al. 2014). Efforts have been dedicated to finding more promising populations of this predator to control $R$. indica (Moraes et al. 2012; Silva et al. 2014). In the present work, $A$. largoensis was not found, whereas $A$. aerialis was among the least abundant species. In the Amazon, in addition to Roraima, A. largoensis has also been found on coconut in the coastal area of Pará state (Lawson-Balagbo et al. 2008), but it has not been reported in other Brazilian Amazonian states nor in the Amazonian region of neighboring countries (see references in Demite et al. 2018). In Roraima, it was found in samples collected in the central and northern part of the state, in the neighborhood of or within savanna areas (Gondim Jr. et al. 2012). Thus, this predator has not been found on palms in the central area of the Amazonian forest, where rainfall and relative humidity are higher. The exact 
reason for this is unknown, but could reflect the inability of this predator to compete with other predators present in the wettest and most densely vegetated areas.

Of the most abundant phytoseiids on the three oil palm groups, A. perditus, was also reported in Manaus region by Bobot et al. (2011), Cruz et al. (2015) and Nuvoloni et al. (2015). Iphiseiodes kamahorae, the second most abundant and found only on American oil palms, was previously reported from Brazil only from rubber trees, also in the Amazon region (Nuvoloni et al. 2015). The absence of representatives of the phytoseiid genera Euseius Wainstein and Neoseiulus Hughes is noteworthy, given their frequent occurrence in other parts of Brazil (Demite et al. 2018) on many plant species. Scarcity of these mites has also been reported by Cruz et al. (2015) in Manaus region and by Argolo et al. (2017) in the southern coast of the Brazilian Bahia state, also a very humid region, with high rainfall, where oil palm is extensively cultivated.

The largest diversity of phytoseiids and largest abundance of predators in general on American oil palms may result from the largest abundance of eriophyoids on those plants. The latter may serve as food to the predators, which may maintain themselves at higher population levels than would occur in the absence of those non-damaging phytophagous mites, rendering the predators potentially more effective as natural enemies of damaging species.

In conclusion, the present work is the first specifically dedicated to the determination of the mite fauna on oil palms in South America. It demonstrated that mites are considerably more numerous and diverse on American than on African oil palms or their respective hybrids. On the three palm groups, the vast majority of the mites in the central part of the Brazilian Amazonian forest consist of phytophagous mites of the superfamily Eriophyoidea, and these are most numerous in the wet season. They cause no significant damage to the oil palm hosts, most certainly because of their low densities and because they belong to reportedly non-damaging groups. Predatory mites on oil palms are predominantly phytoseiids, followed by cunaxids. The phytoseiids $A$. perditus and $I$. kamahorae are the most abundant predators on oil palms, but they are mostly concentrated on some genotypes (the first on BR 174 and Coari, and the second on Manicoré). Eriophyoids may serve as food to the predators, which may be able to maintain themselves at higher population levels than would occur in the absence of those non-damaging phytophages, probably making them potentially more effective as natural enemies of potentially damaging species, such as the threatening $R$. indica.

\section{Acknowledgements}

To Coordenação de Aperfeiçoamento de Pessoal de Nível Superior (CAPES), for the scholarship to the first author. To Embrapa Amazônia Ocidental, for the logistic support in this study. To Nelito M. da Silva, Universidade Federal do Amazonas, for allowing the use of the facilities of the Entomology Laboratory. To Aleuny Countinho Reis for the identification of the eriophioid species.

\section{References}

Argolo, P.S., Santos, R.M.V., Bittencourt, M.A.L., Noronha, A.C. da S., Moraes, G.J. de \& Oliveira, A.R. de (2017) Phytoseiid mites (Acari: Phytoseiidae) associated with tropical ornamental plants, with a checklist and a key to the species of Bahia, Brazil. Zootaxa, 4258, 345-364. https://doi.org/10.11646/zootaxa.4258.4.3

Barcelos, E., Amblard, P., Berthaud, J. \& Seguin, M. (2002) Genetic diversity and relationship in American and African oil palm as revealed by RFLP and AFLP molecular markers. Pesquisa Agropecuária Brasileira, 37, 1105-1114.

https://doi.org/10.1590/S0100-204X2002000800008 
Beard, J.J., Ochoa, R., Bauchan, G.R., Welbourn, W.C., Pooley, C. \& Dowling, A.P.G. (2012) External mouthpart morphology in the Tenuipalpidae (Tetranychoidea): Raoiella a case study. Experimental \& Applied Acarology, 57, 227-255. https://doi.org/10.1007/s10493-012-9540-2

Bobot, T.E., Franklin, E., Navia, D., Gasnier, T.R.J., Lofego, A.C. \& Oliveira, B.M. (2011) Mites (Arachnida, Acari) on Citrus sinensis L. Osbeck orange trees in the State of Amazonas, Northern Brazil. Acta Amazonica, 41, 557-566. https://doi.org/10.1590/S0044-59672011000400013

Brazilio, M., Bistachio, N.J., Perina, V.C.S. \& Nascimento, D.D.do (2012) Revisão: o dendezeiro (Elaeis guineensis Jacq.). Bioenergia em revista: diálogos, 2, 27-45.

Castro, T.M.M.G. \& Moraes, G.J. (2007) Mite diversity on plants of different families found in the Brazilian Atlantic Forest. Neotropical Entomology, 36, 774-782. https://doi.org/10.1590/S1519-566X2007000500020

Carrillo, D., Amalin, D., Hosein, F., Roda, A., Duncan, R.E. \& Peña, J.E. (2012a) Host plant range of Raoiella indica (Acari: Tenuipalpidae) in areas of invasion of the New World. Experimental \& Applied Acarology, 57, 271-289. https://doi.org/10.1007/s10493-011-9487-8

Carrillo, D., Coss, M.E., Hoy, M.A. \& Peña, J.E. (2011) Variability in response of four populations of Amblyseius largoensis (Acari: Phytoseiidae) to Raoiella indica (Acari: Tanuipalpidae) and Tetranychus gloveri (Acari: Tetranychidae) eggs and larvae. Biological Control, 60, 39-45. https://doi.org/10.1016/j.biocontrol.2011.09.002

Carrillo, D., Frank, J.H., Rodrigues, J.C.V. \& Peña, J.E. (2012b) A review of the natural enemies of the red palm mite, Raoiella indica (Acari: Tenuipalpidae). Experimental \& Applied Acarology, 57, 347-360. https://doi.org/10.1007/s10493-011-9499-4

Carrillo, D., Hoy, M.A. \& Peña, J.E. (2014) Effect of Amblyseius largoensis (Acari: Phytoseiidae) on Raoiella indica (Acari: Tenuipalpidae) by predator exclusion and predator release techniques. Florida Entomologist, 97, 256-261. https://doi.org/10.1653/024.097.0134

Cocco, A. \& Hoy, M.A. (2009) Feeding, reproduction, and development of the red palm mite (Acari: Tenuipalpidae) on selected palms and banana cultivars in quarantine. Florida Entomologist, 92, 276-291. https://doi.org/10.1653/024.092.0212

Cruz, W.P., Krug, C., Vasconcelos, G.J.N. \& Moraes, G.J. (2015) Diversity of mites associated with Raoiella indica (Acari: Prostigmata) on coconut palms in the central region of the Brazilian Amazonia, with emphasis on the predaceous Phytoseiidae (Acari: Mesostigmata). Systematic and Applied Acarology, 20, $875-886$. https://doi.org/10.11158/saa.20.8.4

Cunha, R.N.V. da, Lopes, R., Rocha, R.N.C. da, Lima, W.A.A. de, Teixeira, P.C., Barcelos, E., Rodrigues, M.R.L. \& Rios, S. A. (2012) Domestication and breeding of the American oil palm. In: Borém, A, Lopes, M.T.G, Clement, C.R \& Noda, H. (Eds.) Domestication and breeding: Amazonian species. Viçosa, UFV. pp. 275-296.

Demite, P.R., Cruz, W.P. da \& Cavalcante, A.C.C. (2019) A new species of Phytoscutus Muma (Acari: Mesostigmata: Phytoseiidae) from Amazonas state, Brazil, with redefinition of the sexpilis species group Chant \& McMurtry and a key to the world species of the genus. Systematic and Applied Acarology, 24(8), 1533-1540. https://doi.org/10.11158/saa.24.8.13

Demite, P.R., Cruz, W.P. da, McMurtry, J.A. \& Moraes, G.J. from (2017) Amazoniaseius imparisetosus n. sp., n.g.: an unusual new phytoseiid mite (Acari: Phytoseiidae) from the Amazon forest. Zootaxa, 4236(2), 302-310. http://dx.doi.org/10.11646/zootaxa.4236.2.5

Demite, P.R., Feres, R.J.F., Lofego, A.C. \& Oliveira, A.R. (2009) Plant inhabiting mites (Acari) from the Cerrado biome of Mato Grosso State, Brazil. Zootaxa, 2061, 45-60. https://doi.org/10.11646/zootaxa.2061.1.3

Demite, P.R., Moraes, G.J., McMurtry, J.A., Denmark, H.A. \& Castilho, R.C. (2018) Phytoseiidae database. Database in digital format. www.lea.esalq.usp.br/phytoseiidae. Accessed September 122018.

Den Heyer, J. \& Hernandes, F.A. (2017) Bdelloidea Base: Bdellid \& Cunaxid Databases (version Feb 2013). 
In: Roskov, Y., Abucay L., Orrell, T., Nicolson, D., Bailly, N., Kirk, P.M., Bourgoin, T., DeWalt, R.E., Decock, W., De Wever, A., Nieukerken, E. van, Zarucchi, J. \& Penev, L. (Eds.), Species 2000 \& ITIS Catalogue of Life, 29th September 2017. Leiden, the Netherlands. Database in digital format. www.catalogueoflife.org/col. Accessed January 222017.

Domingos, C.A., Oliveira, L.O., Morais, E.G.F., Navia, D., Moraes, G.J. \& Gondim Jr., M.G.C. (2013) Comparison of two populations of the pantropical predator Amblyseius largoensis (Acari: Phytoseiidae) for biological control of Raoiella indica (Acari: Tenuipalpidae). Experimental \& Applied Acarology, 60, 83-93. https://doi.org/10.1007/s10493-012-9625-y

Ferla, N.J. \& Moraes, G.J. (2008) Flutuação populacional e sintomas de dano por ácaros (Acari) em seringueira no estado do Mato Grosso, Brasil. Revista Árvore, 32, 365-376. https://doi.org/10.1590/S0100-67622008000200019

Flechtmann, C.H.W. \& Noronha, A.C. (2011) A new red spider mite from the African oil palm from Brazil (Acari: Tetranychidae). Systematic and Applied Acarology, 16, 67-72. https://doi.org/10.11158/saa.16.1.9

Gondim, M.G.C., Jr., Castro, T.M.M.G., Marsaro Jr., A.L., Navia, D., Melo, J. W.S., Demite, P. \& Moraes, G.J. (2012) Can the red palm mite threaten the Amazon vegetation? Systematics \& Biodiversity, 10, 527-535. https://doi.org/10.1080/14772000.2012.752415

Gondim, M.G.C., Jr., Flechtmann, C.H.W. \& Moraes, G.J. (2000) Mite (Arthropoda: Acari) associates of palms (Arecaceae) in Brazil: IV. Descriptions of four new species in the Eriophyoidea. Systematic and Applied Acarology, 5, 99-100. https://doi.org/10.11158/saa.5.1.12

Henderson, J. \& Osborne, D.J. (2000) The oil palm in all our lives: how this came about. Endeavour, 24, 63-68. https://doi.org/10.1016/S0160-9327(00)01293-X

Hoy, M.A., Peña, J. \& Nguyen, R. (2012) Red palm mite, Raoiella indica Hirst (Arachnida: Acari: Tenuipalpidae). IFAS Extensions. Available in: http://entomology.ifas.ufl.edu/creatures. Accessed June 122018.

Krantz, G.W. \& Walter, D.E. (2009) A manual of acarology. 3nd ed. Lubbock, Texas Tech University Press, $807 \mathrm{pp}$.

Lawson-Balagbo, L.M., Gondim Jr., M.D.C., Moraes, G.J., Hanna, R. \& Schausberger, P. (2008) Exploration of the acarine fauna on coconut palm in Brazil with emphasis on Aceria guerreronis (Acari: Eriophyidae) and its natural enemies. Bulletin of Entomological Research, 98, 83-94. https://doi.org/10.1017/S0007485307005421

McMurtry, J.A., Moraes, G.J. \& Sourassou, N.F. (2013) Revision of the lifestyles of phytoseiid mites (Acari: Phytoseiidae) and implications for biological control strategies. Systematic \& Applied Acarology, 18, 297-320. https://doi.org/10.11158/saa.18.4.1

Moraes, G.J. de, Britto, E.P.J., Mineiro, J.L. de C. \& Halliday, B. (2016) Catalogue of the mite families Ascidae Voigts \& Oudemans, Blattisociidae Garman and Melicharidae Hirschmann (Acari: Mesostigmata). Zootaxa (Auckland), 4112(1), 1-299. https://doi.org/10.11646/zootaxa.4112.1.1

Moraes, G.J., Castro, T.M.M.G., Kreiter, S., Quilici, S., Gondim Jr., M.G.C. \& Sá, L.A.N. (2012) Search for natural enemies of Raoiella indica Hirst in Réunion Island (Indian Ocean). Acarologia, 52, 129-134. https://doi.org/10.1051/acarologia/20122043

Navia, D., Marsaro, A.L., Jr., Silva, F.R., Gondim Jr., M.G.C. \& de Moraes, G.J. (2011) First report of the red palm mite, Raoiella indica Hirst (Acari: Tenuipalpidae), in Brazil. Neotropical Entomology, 40, 409-411. https://doi.org/10.1590/S1519-566X2011000300018

Navia, D., Gondim, M.G.C., Jr., Aratchige, N.S. \& Moraes, G.J. (2013) A review of the status of the coconut mite, Aceria guerreronis (Acari: Eriophyidae), a major tropical mite pest. Experimental \& Applied Acarology, 59, 67-94. https://doi.org/10.1007/s10493-012-9634-x

Navia, D. \& Flechtmann, C.H.W. (2005) A new genus and five new species of Eriophyoidea (Prostigmata) associated with palm trees from Brazilian Amazon. Zootaxa, 1078, 41-58. https://doi.org/10.11646/zootaxa.1078.1.4

Nuvoloni, F.M., Lofego, A.C., Rezende, J.M. \& Feres, R.J.F. (2015) Phytoseiidae mites associated with Hevea spp. from the Amazon region: a hidden diversity under the canopy of native trees. Systematics \& Biodiversity, 13, 182-206. 
https://doi.org/10.1080/14772000.2014.985344

Ochoa, R., Beard, J.J., Bauchan, G.R., Kane, E.C., Dowling, A.P.G. \& Erbe, E.F. (2011) Herbivore exploits chink in armor of host. American Entomologist, 57, 26-29.

https://doi.org/10.1093/ae/57.1.26

Oliveira, D.C., Moraes, G.J. \& Dias, C.T.S. (2012) Status of Aceria guerreronis Keifer (Acari: Eriophyidae) as a pest of coconut in the State of Sao Paulo, southeastern Brazil. Neotropical Entomology, 41, 315-323. https://doi.org/10.1007/s13744-012-0051-y

Peláez, E., Ramirez, D. \& Cayón, G. (2010) Fisiología comparada de palmas africana (Elaeis guineensis Jacq.), americana (Elaeis oleifera H.B.K. Cortes) e híbridos (E. oleifera x E. guineensis) en Hacienda La Cabaña. Palmas, 31, 29-38.

R Core Team, (2015) R Foundation for Statistical Computing, version 3.1.2. Vienna, Austria. Available in: http://www. R-project.org

Rai, A.B., Jhala, R.C., Patel, C.B., Patel, V.J., Patel, K.G. \& Shah, A.H. (1991) Ecology of Oligonychus indicus (Acarina, Tetranychidae) infesting coconut in South Gujarat, India. Modern Acarology, 1-2, 559-563.

Rodrigues, J.C.V. \& Antony, M.K. (2011) First report of Raoiella indica (Acari: Tenuipalpidae) in Amazonas state, Brazil. Florida Entomologist, 94, 1073-1074. https://doi.org/10.1653/024.094.0452

Santana, D.L.Q. \& Flechtmann, C.H.W. (1998) Mite (Arthropoda, Acari) associates of palms (Arecaceae) in Brazil: Present status and new records. Revista Brasileira de Zoologia, 15, 959-963. https://doi.org/10.1590/S0101-81751998000400014

Silva, R.V., Narita, J.P.Z., Vichitbandha, P., Chandrapatya, A., Konvipasruang, P., Kongchuensin, M. \& Moraes, G.J. (2014) Prospection for predatory mites to control coconut pest mites in Thailand, with taxonomic descriptions of collected Mesostigmata (Acari). Journal of Natural History, 48, 699-719. https://doi.org/10.1080/00222933.2013.839842

Skvarla, M.J., Fisher, J.R. \& Dowling, A.P.G. (2014) A review of Cunaxidae (Acariformes, Trombidiformes): Histories and diagnoses of subfamilies and genera, keys to world species, and some new locality records. Zookeys, 418, 1-103. https://doi.org/10.3897/zookeys.418.7629

StatSoft, (2015) Statistica for Windows: software system for data-analyses, version 12.1. Tulsa, StatSoft, 166 pp.

Wahid, M.B., Abdullah, S.N. \& Henson, I.E. (2005) Oil Palm - Achievements and potential. Plant Production Science, 8, 288-297. https://doi.org/10.1626/pps.8.288

Welbourn, C. (2009) Pest alert: red palm mite, Raoiella indica Hirst (Acari: Tenuipalpidae). In: Florida Department of Agriculture and Consumer Services. Available in: http://www.doacs.state.fl.us/pi/enpp/ento/ r.indica.html and http://www.doacs.state.fl.us/pi/caps/rpm_maps/RPM_Base_Map_34x44.pdf.

Submitted: 7 Apr. 2019; accepted by Guilherme da Silva: 20 Jul. 2019; published: 25 Sep. 2019 